\section{J. Engel ${ }^{\mathrm{a}}, M$. Schmidt \\ J. Scheichenzuber ${ }^{\mathrm{a}}$, B. Reimer ${ }^{\mathrm{a}}$ \\ D. Hölzel ${ }^{\mathrm{b}}$, H. Sauer}

a Tumorzentrum München,

${ }^{\mathrm{b}}$ Institut für Informatik, Biometrie und

Epidemiologie (IBE), und

c Medizinische Klinik III, Klinikum Großhadern

for all involved hospital departments

\title{
Population-Based Patient Care Study for Breast Cancer
}

\section{Key Words}

Quality management $\cdot$ Breast Cancer $\cdot$ Population-based $\cdot$ Cancer registry Quality of life

\section{Summary}

Background: Different approaches for an effective quality management are funded by the Ministry of Health to verify, to assess and, if necessary, to optimize the quality of health care using the tracer diagnoses of breast, rectal, and lung cancer in eight regions in Germany. The conception of these observational studies and initial findings are shown here, using breast cancer in the region of Munich (population 2.4 million) as an example. Patients and Methods: The study started on April 1,1996. The recruitment phase for all primary breast cancer patients in this region is planned for 2 years with a 3-5-year follow-up. Established documentation sheets are used to document basic medical information of each patient, along with the original reports (pathology, radiotherapy, doctors' reports, etc.), follow-up reports and quality of life questionnaires (QLQ, including the EORTC QLQ C30). Results: In 1996, the Munich region has a crude incidence of 125/100,000 women (world standard 71.5). After almost complete documentation the incidence is $10-15 \%$ higher. In the period from April 1, 1996 to June 30, 1997 1,360 patients have been recruited into the study. $79 \%$ of the patients were 50 years of age or older. pT stages are distributed as follows: pTIS $5 \%$, pT1 54\%, pT2 32\%, pT3 4\%,pT4 6\%. $4.5 \%$ had primary metastases. Breast-conserving therapy (BCT) was performed in $57 \%$ of patients. Five of the 46 departments involved recruited more than 50 patients each within these 14 months. These larger departments treat $59 \%$ of all patients. The proportion of older patients and pT4 stages is significantly higher in the smaller departments. BCT is performed significantly more often in the larger departments. First results of quality of life show dependencies on age, but no differences between mastectomy and BCT 3 months after operation. Not only the addressed patients (response rate to QLQ over $80 \%$ ) but also almost all hospitals and many physicians are willing to support and to partake in quality assurance. 35 hospitals, 46 surgical departments, 80 heads of department and surgically active general practioners, 330 general practioners, 7 radiotherapy departments, and 13 pathology departments have so far documented for this study. Conclusions: An effective quality management in oncology needs a modern cancer registry which uses documentation sheets as well as original reports and organizes the complicated infrastructure for an interdisciplinary cooperation. To be able to evaluate the health care reality, it is necessary to carry out a data analysis and assess each individual case. A feedback of the results have to be available for each physician and each department. The cost of this information management is approximately $0.3 \%$ of the health care cost for this group of patients.

\section{Schlüsselwörter}

Qualitätsmanagement · Mammakarzinom · Bevölkerungsbezogen · Tumorregister $\cdot$ Lebensqualität

\section{Zusammenfassung}

Hintergrund: Als Modellprogramm für ein effektives Qualitätsmanagement werden anhand der Tracerdiagnosen Mamma-, Rektum- und Lungenkarzinom in 8 Regionen Deutschlands sogenannten Feldstudien vom Bundesministerium für Gesundheit (BMG) gefördert, um die Qualität der Versorgung zu belegen, zu bewerten und gegebenenfalls zu optimieren. Für die Region München (2,4 Mill. Einwohner) werden die Konzeption und erste Ergebnisse einer solchen Beobachtungsstudie zum Mammakarzinom vorgestellt. Patienten und Methoden: Beginn der Studie war der 1. April 1996. Flächendeckend sollen zunächst innerhalb von 2 Jahren alle Neuerkrankungen an Brustkrebs in dieser Region erfaßt und 3-5 Jahre nachbeobachtet werden. Als Erfassungsinstrumente dienen etablierte Erhebungsbögen zu den medizinischen Basisdaten, Originalberichte (Pathologiebefunde, Arztbriefe usw.), Folgeerhebungsbögen und Lebensqualitätsfragebögen, welche auch den Fragebogen der EORTC (QLQ C30) beinhalten. Ergebnisse: Für das Jahr 1996 wurde für das Stadtgebiet München eine rohe Inzidenz von 125/100 000 Frauen (Weltstandard 71,5) ermittelt. Nach vollständiger Erfassung werden die Inzidenzen noch 10-15\% höher liegen. Vom 1. April 1996 bis zum 30. Juni 1997 wurden 1360 Patientinnen rekrutiert. 79\% der Patientinnen waren 50 Jahre und älter. Die pT-Stadien waren wie folgt verteilt: pTIS 5\%,pT154\%,pT2 32\%, pT3 4\%, pT4 6\%. Primär metastasiert waren 4,5\%. Eine brusterhaltende Therapie (BET) wurde in 57\% der Fälle durchgeführt. In den 14 Monaten rekrutierten 5 der insgesamt 46 beteiligten Abteilungen jeweils mehr als 50 Patientinnen. In diesen größeren Abteilungen werden 59\% aller Patientinnen versorgt. Der Anteil der älteren Patientinnen über 70 Jahre und der pT4-Stadien ist in den kleineren Kliniken signifikant höher. Eine BET wird in den größeren Kliniken signifikant öfter durchgeführt. Erste Ergebnisse zur Lebensqualität zeigen 3 Monate nach Operation Abhängigkeiten vom Alter, aber keine Unterschiede zwischen Mastektomie und BET. Neben den angeschriebenen Patientinnen (Rückfallquote über 80\%) sind fast alle Krankenhäuser und viele Ärzte bereit, Qualitätssicherung zu unterstützen. 35 Krankenhäuser, 46 operative Abteilungen, 80 Klinik- und Abteilungsleiter und operativ tätige Belegärzte, 330 niedergelassene Ärzte, 7 Strahlentherapie- und 13 Pathologie-Abteilungen haben bisher Dokumentationsbeiträge geliefert. Schlußfolgerungen: Effektives Qualitätsmanagement in der Onkologie erfordert ein modernes Krebsregister mit einer Dokumentation über Erhebungsbögen sowie Originaldokumente, das die komplizierte Infrastruktur für eine interdisziplinäre $\mathrm{Zu}$ sammenarbeit organisiert. Zur Beurteilung der Versorgungsrealität ist eine Datenanalyse und die Bewertung jedes Einzelfalles notwendig. Ein Feedback der Ergebnisse muß für jeden Arzt und jede Klinik gegeben sein. Die Kosten für dieses Informationsmanagement dürften bei zirka 0,3\% der Versorgungskosten der Patienten liegen.

\begin{tabular}{ll}
\hline KARGER & $\begin{array}{c}\text { @ } 1998 \text { S. Karger GmbH, Freiburg } \\
\text { Fax (0761) } 4520714 \\
\text { www.karger.com }\end{array}$ \\
& \\
This article is also accessible online at: http://BioMedNet.com/karger
\end{tabular}




\section{Introduction}

\section{Aim}

The Ministry of Health is funding different approaches for the documentation and support of regional health care of cancer patients in eight regions in Germany. These approaches are tested on the tracer diagnoses of lung, rectal, and breast cancer. The conception of one of these studies and the initial findings are shown here, using breast cancer in the region of Munich as an example.

The aim of the study is to assess the medical care of all patients with primary breast cancer and to evaluate the care carried out according to the accepted standards of medical knowledge. These requirements define this population-based observational study and with that a modern cancer registration which verifies the health care from screening to therapy and outcome [1-4]. The important indicators such as incidence, stage distribution and relevant prognostic factors, surgical and conservative therapeutic measures, side effects, and finally survival rates must be available [5-8]. The quality of life of the patients is an important additional parameter [9, 10]. With this knowledge the quality of health care can be verified and optimized, if necessary. In this study, suitable methods for meaningful documentation, pathways of information exchange, and effective quality management in oncology are developed and tested so that they can later be used in the routine care of cancer patients.

\section{Patient Care in Munich and the Surrounding Area}

The realization of a cancer registry depends particularly on the structure of the health care system. The German health care system is decentralized with a separation of inpatient and outpatient care. This complicates the work of the approximately 40 tumor centers which are mainly managed by the universities. The size of the region of a single comprehensive cancer center varies from 1 to 5 million inhabitants. Munich and the surrounding area (fig. 1) has a population of 2.4 million, of which 9,800 per year will develop cancer, with a prevalence of approximately 40,000 patients with former or current malignant disease.

\section{Patients and Methods}

The study started on April 1, 1996. All patients who develop breast cancer after this date and have their place or residence in Munich or the surrounding area are included in the study. The recruitment phase is planned for 2 years with a follow-up of 3-5 years. In the Munich region almost all hospitals are involved. Physicians from both the in- and outpatient sector as well as the patients themselves cooperate well in the documentation of the complete course of the disease. Minimal information on screening, diagnostics, therapy, and follow-up as well as palliative care are registered on documentation sheets. Verification of residence within the Munich region is also documented. In addition, the original reports from the pathology, surgery, radiotherapy and adjuvant chemotherapy or hormonal treatment are availabe. The use of original reports minimizes the work effort for the physicians and transfers it to the registry.

The initial report of each patient by means of documentation sheets and original reports is carried out independently by the clinician involved in the primary treatment. On the other hand, the cancer center receives the pathology reports directly from the pathological institutes of the region.

For the update of the information, documents are regularly mailed to the practitioners involved in the posttreatment care. These forms already contain the known treatment and follow-up data of the individual patient so that the physicians only have to fill in the most recent results.

When the patient's written consent is received from the hospital, the patients are asked 3 months following operation and then every 6 months about their subjective opinion on quality of life as well as medical treatment and personal care. The EORTC QLQ C30 (EORTC quality of life questionnaire, core module 30 ) is part of this documentation of quality of life $[9,10]$.

After completion of all these documents, sufficient information on the actual health care can be achieved. Only some essential aspects are evaluated for this preliminary presentation, but the original reports offer additional detailed information for nested studies, which will be carried out later regarding specific questions.
Fig. 1. The health care providers (in the ellipse) and their contribution in the Munich region. Qol = Quality of life.

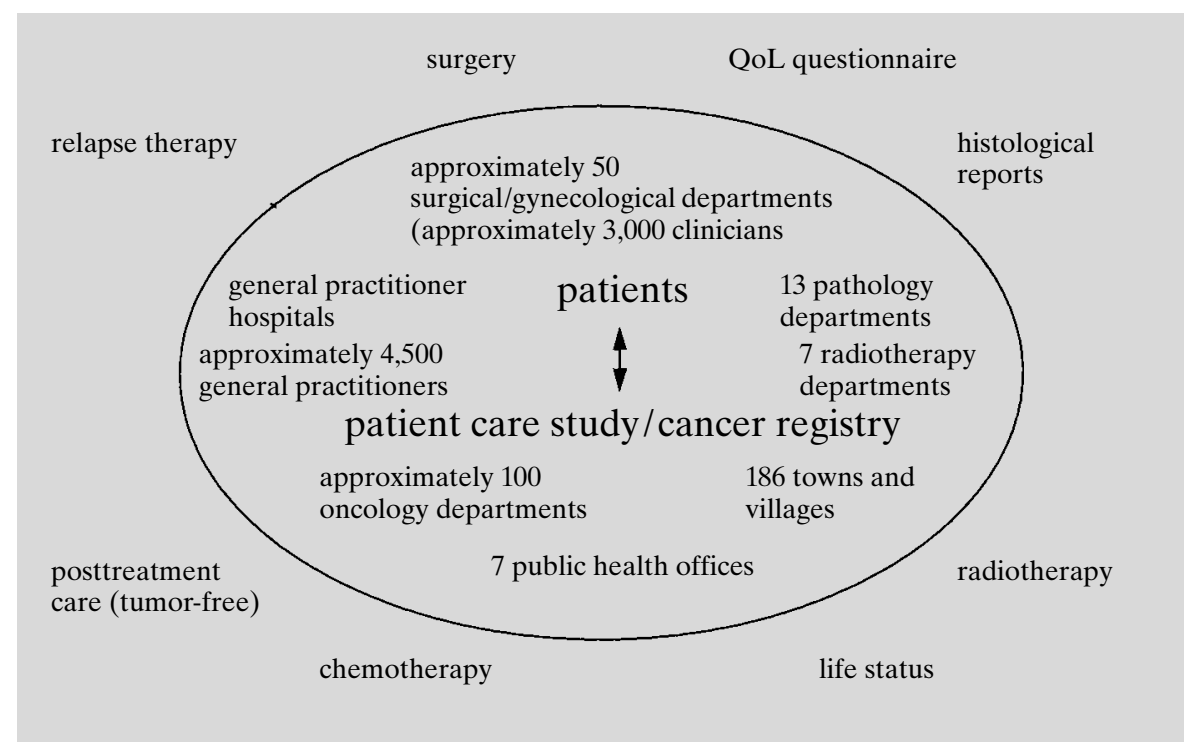




\section{Results}

Approximately 2,000 primary breast cancer cases per year are treated in the region of which 1,600 have their place of residence within the defined region and which can therefore be included in the study. From April 1, 1996 to June 30, 1997, 1,360 patients have been recruited in the region of Munich and the surrounding area. This means approximately $85 \%$ of cases have been recruited within the 1st year of the study and verify a higher incidence for this region than originally expected (fig. 2). An exact calculation of incidence will only be possible once the documentation is completed (including place of residence). In an other patient care study, a crude incidence of 125/100,000 women was reached also (information supplied by Tumor Registry Aachen, unpublished data). Up to now the only other incidence data in Germany have been available from the Saarland with a crude incidence of 102.4/100,000 women and from a world standard of 57.0/100,000 for 1993 .

Table 1 shows the distribution of pT stage according to the detection modality of breast cancer. Correlation between screening and stage distribution shows a shift to pT1 stage with an assumed possibility of reduction in mortality. The stage shift caused by regular screening could reduce mortality up to $35 \%$ of the group without regular screening. The benefit of $35 \%$ can be calculated from the stage-specific survival rates and the stage shift by screening. The official screening programm in Germany only involves palpation, but most of the tumors were proven by mammography. Thus, whether the data 'regular screening' includes mammography or not cannot be answered reliably.

Tables 2 and 3 show the distribution of elementary clinical data. This population-based registration gives an epidemiological description of breast cancer and health care in the region of Munich. The mean age rises by one year between pT 1 and pT 3. There is a relatively high proportion of pT 1 with $54 \%$ (table 2). In another patient care study in Germany (region of Aachen) only $33 \%$ pT 1 could be ascertained (information supplied by Tumor Registry Aachen, unpublished data). The proportion of breast-conserving therapy (BCT) in the region is $57 \%$. Stage pT 1a is conspicuous with a larger proportion of multifocality/multicentricity and a larger proportion of tumors with an intraductal component. This is also reflected in the surgical therapy (table 3 ).

Initial results are also available for 3 other regions (Aachen, Jena, Marburg) [11], and we expect to see considerable regional variability which also seems noticeable between the health care providers. Tables 4 and 5 show variations of age, pT stages, and proportion of BCT between the hospitals as elementary examples. In Germany breast cancer is treated by gynecologists and surgeons. In the Munich region there are 46 departments which operate on breast cancer patients. The two groups shown are divided according to numbers of recruited patients. Smaller hospitals have not only a larger proportion of older patients $(\mathrm{p}<0.001)$ but also more advanced pT stages (not shown) (table 4). Despite the same distribution of multifocality/multicentricity and intraductal components, there is a significant difference of method of operation $(\mathrm{p}<0.001)$ between departments: A higher proportion of BCT is carried out in the larger departments especially for the most frequent stages pT 1 and pT 2 (table 5).

Figure 3 shows first results of quality of life examination (EORTC QLQ C30) in different subgroups 3 months following the operation. For comparison, the quality of life is shown in respect to method of operation (BCT and mastectomy) as well as age under 50 years and over 70 years. There is no difference in the quality of life between patients with BCT and those with mastectomy. Differences of opinion are seen between the two age groups, the younger patients $(<50$ years) reporting a worse quality of life. The results for the patients between 50 and 70 years (not shown in the graph) are about the mean of the presented groups of age. The questionnaires filled in by the patients are a valuable source of additional

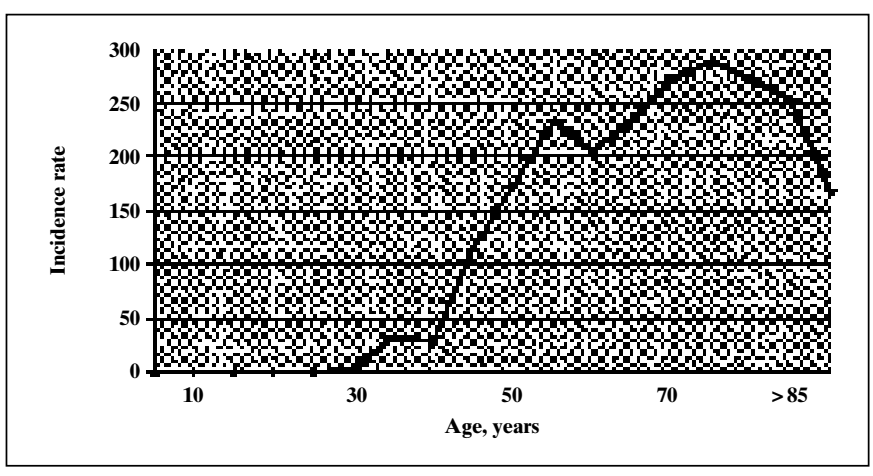

Fig. 2. Age-specific incidence rates for 1996 (for Munich). Mean age at diagnosis: 60.8 years. Crude incidence $125 / 100,000$ women, world standard $71.5 / 100,000$. The incidence rate will be approximately $15 \%$ higher when documentation is complete.
Table 1. Distribution of pT stages and screening $^{\mathrm{a}}$

\begin{tabular}{|c|c|c|c|c|c|c|}
\hline \multirow[t]{3}{*}{ pT stage } & \multicolumn{2}{|c|}{ Regular self-examination } & \multicolumn{2}{|c|}{ Regular screening } & \multicolumn{2}{|c|}{ Regular screening } \\
\hline & yes & & yes & & $\begin{array}{l}\text { discovered at } \\
\text { appointment }\end{array}$ & $\begin{array}{l}\text { discovered before } \\
\text { appointment }\end{array}$ \\
\hline & $\mathrm{n}=317$ & $\mathrm{n}=244$ & $\mathrm{n}=323$ & $\mathrm{n}=246$ & $\mathrm{n}=169$ & $\mathrm{n}=143$ \\
\hline pT 1 & 57 & 55 & 68 & 41 & 79 & 55 \\
\hline pT 2 & 32 & 33 & 27 & 40 & 18 & 39 \\
\hline pT 3 & 6 & 3 & 2 & 8 & 2 & 4 \\
\hline pT 4 & 4 & 8 & 2 & 11 & 1 & 3 \\
\hline
\end{tabular}

${ }^{\mathrm{a}}$ An effect of screening is verified by the shift to more favorable stages. 
Table 2. Clinical data according to $\mathrm{pT}$ stage $^{\mathrm{a}}$

\begin{tabular}{|c|c|c|c|c|c|c|c|c|}
\hline pT stage & $\begin{array}{l}\text { All } \\
\text { patients }\end{array}$ & $\begin{array}{l}\text { Age group } \\
<50 \text { years } \\
(21 \%) \\
\%\end{array}$ & $\begin{array}{l}\text { Age group } \\
50-69 \text { years } \\
(52 \%) \\
\%\end{array}$ & $\begin{array}{l}\text { Age group } \\
>70 \text { years } \\
(27 \%) \\
\%\end{array}$ & $\begin{array}{l}\text { Mean } \\
\text { age } \\
\text { years }\end{array}$ & $\begin{array}{l}\text { Proportion } \\
\mathrm{N}+ \\
(36 \%) \\
\%\end{array}$ & $\begin{array}{l}\text { Proportion } \\
\text { G 3 } \\
(36 \%) \\
\%\end{array}$ & $\begin{array}{l}\text { Proportion } \\
\text { M } 1 \\
(4.5 \%) \\
\%\end{array}$ \\
\hline pTis & 5 & 5 & 5 & 4 & 60.6 & 0 & 41 & 0 \\
\hline pT 1 & 54 & 51 & 59 & 45 & 59.7 & 25 & 26 & 2 \\
\hline pT 1a & 5 & 4 & 6 & 3 & 58.3 & 15 & 27 & 0 \\
\hline pT 1b & 12 & 10 & 13 & 10 & 60.6 & 14 & 18 & 2 \\
\hline pT 1c & 37 & 37 & 40 & 32 & 59.6 & 29 & 29 & 2 \\
\hline pT 2 & 32 & 36 & 30 & 34 & 60.9 & 49 & 47 & 4 \\
\hline pT 3 & 4 & 4 & 4 & 5 & 61.9 & 72 & 58 & 13 \\
\hline pT 4 & 6 & 3 & 3 & 13 & 71.2 & 71 & 38 & 29 \\
\hline
\end{tabular}

${ }^{\mathrm{a}} \mathrm{n}=1,282$ with data to all items.

Table 3. Multifocality/multicentricity, intraductal component, and proportion of BCT according to $\mathrm{pT}$ stage ${ }^{\mathrm{a}}$

\begin{tabular}{llll}
\hline pT stage & $\begin{array}{l}\text { Multiple } \\
(\mathrm{n}=217) \\
\text { proportion in \% }\end{array}$ & $\begin{array}{l}\text { Intraductal component } \\
(\mathrm{n}=391) \\
\text { proportion in \% }\end{array}$ & $\begin{array}{l}\text { BCT } \\
(\mathrm{n}=1,260) \\
\text { proportion in \% }\end{array}$ \\
\hline pT 1a & 31 & 66 & 50 \\
pT 1b & 18 & 31 & 76 \\
pT 1c & 14 & 35 & 69 \\
pT 2 & 20 & 28 & 53 \\
pT 3 & 21 & 17 & 6 \\
pT 4 & 8 & 10 & 10 \\
Total & 17 & 31 & 57
\end{tabular}

${ }^{a}$ The intraductal component is presented as a general term and has still to be evaluated as quantity, as described in the pathological reports.

Table 4. Distribution of different age groups according to department magnitude

\begin{tabular}{lll}
\hline Age at diagnosis & $\begin{array}{l}\text { Department groups } \\
\text { according to number of treated (study-) patients }\end{array}$ \\
\cline { 2 - 3 } & $\begin{array}{l}\text { 41 departments } \\
\text { with }<50 \text { patients }(\mathrm{n}=559) \\
\text { proportion in \% }\end{array}$ & $\begin{array}{l}5 \text { departments } \\
\text { with } \geq 50 \text { patients }(\mathrm{n}=801) \\
\text { proportion in } \%\end{array}$ \\
\hline$<50$ years & 36 & 64 \\
$50-69$ years & 35 & 65 \\
$>=70$ years & 55 & 45 \\
Total & 41 & 59 \\
\hline
\end{tabular}

information. Over $80 \%$ of the patients addressed took the time to answer the extensive questionnaire, which confirms they want to be involved. The patient's reports of actual health care and tumor-specific health problems are an important contribution to the descriptions of health care reality (fig. 3).
Table 5. Proportion of BCT in the two department groups (see table 4)

\begin{tabular}{|c|c|c|}
\hline \multirow[t]{2}{*}{ pT stage } & \multicolumn{2}{|l|}{ Proportion of BCT, \% } \\
\hline & $\begin{array}{l}\text { Department group with } \\
<50 \text { patients }\end{array}$ & $\begin{array}{l}\text { Department group with } \\
\geq 50 \text { patients }\end{array}$ \\
\hline pTis & 35 & 56 \\
\hline pT 1a & 47 & 51 \\
\hline pT $1 b$ & 68 & 79 \\
\hline pT 1c & 58 & 75 \\
\hline pT 2 & 40 & 62 \\
\hline pT 3 & 4 & 7 \\
\hline pT 4 & 10 & 11 \\
\hline
\end{tabular}

\section{Conclusions}

\section{Quality Management}

To be able to make a statement about the quality of medical care, it is necessary to have access to information about the medical care provided [12]. This first step is almost achieved, and a first selection of results can be presented. The actual medical care must be evaluated according to recommended standards e.g. approved guidelines for diagnostics, treatment and follow-up of the respective disease [13-16]. Such an optimized concept of health care must be compared with the reality of the documented information. For years the Comprehensive Cancer Center in Munich has provided standards in the form of manuals for the most frequent tumors. Clinicians and general practitioners meet regularly in tumor-specific project groups to update these guidelines according to accepted scientific knowledge and criteria of evidence-based-medicine (EBM) [17, 18]. In addition to these guidelines for medical procedures, this patient care study has developed recommendations for the content of all clinical reports to reduce the heterogeneity and to make sure that all relevant information is documented. These recommendations have been published and distributed within the region [19-21]. 
Fig. 3. Results of the self-assessment of quality of life (EORTC QLQ C30) approximately 3 months following the operation or diagnosis. Qol = Quality of life.

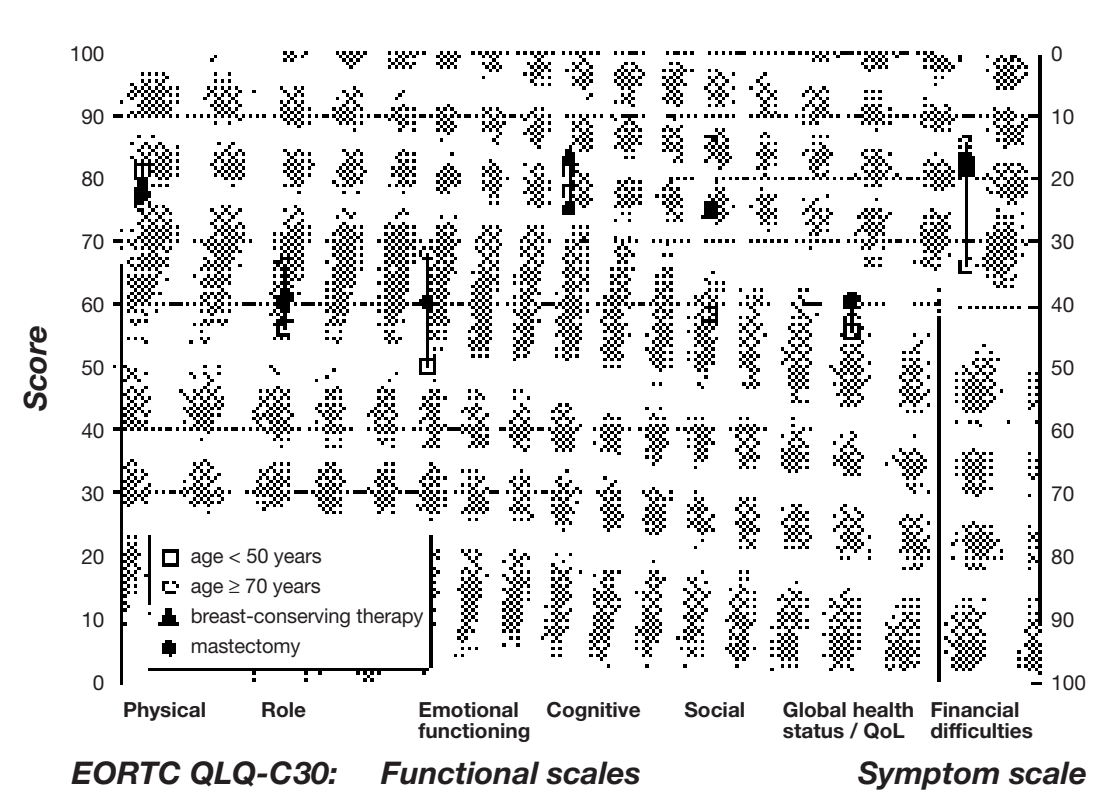

\section{Reality of Medical Care}

To evaluate the reality of medical care, it is necessary to assess each case individually using all documents. Firstly, the information content of each report is evaluated: What does this report convey? Secondly, the medical procedures are assessed according to the given guidelines. The categories are: procedure indicated/not indicated, carried out/not carried out, deviation justifiable or substantiated/wrong. The data analysis delivers the epidemiological results including quality of life and variations between the hospitals by evaluation of crucial parameters of health care [2, 3, 7, 22-24]. Finally, the assessment of the therapeutical procedures according to the above-mentioned categories and the data analysis results of each health care provider must be known.

\section{Communication}

Communication is an important part of an effective quality management. This begins with good availability of standards (lectures, postage of specific guidelines to selected health care providers, manuals). This study provides information e.g. by fax server: +49 $897400567-\mathrm{XXXX}$ (document number, 0004 $=$ list of contents) and Internet at http://www.krebsinfo.de.

A feedback of the results and the long-term outcome including individual cases must be made available to all practitioners and clinical departments involved in the medical care. Rare occurrences, casuistics, and internal statistics have to be made available to the responsible physicians. Conspicuousness or deviation from standard by a hospital or a practitioner in comparision to the average results or to the guidelines are to be pointed out and should motivate autonomous self-regu- lation. Criteria for positive and negative deviations from guidelines are composed (by an independent panel of specialists) with which the casuistics and hospital statistics are assessed and interpreted. This information will be passed onto a hospital or practitioner as a kind of external quality review. The success depends purely on the willingness to discuss such discrepancies.

\section{Cost}

An important aspect of medical quality management are the costs. A modern industry invests up to $10 \%$ of the balance account in its information management. Investment is also necessary in medicine for an effective 'production of health'. In Germany, 257 billion DM was spent on treatment in 1994, approximately 35 to 40 billion of that on cancer treatment. About $0.3 \%$ of that sum would be necessary for the support of an adequate information management. In other words, $1 \mathrm{DM}$ per inhabitant per year. Therefore, it is not a question whether it is affordable or not. It is obligatory as support for a high-quality, appropriate health care. All health care providers should integrate this account into their regular budgets.

\section{Acknowledgements}

This report is dedicated to all departments and all persons involved in documentation not listed: 35 hospitals, 46 surgical and gynecological departments, 80 heads of departments and surgically active general practitioners, 330 general practitioners, 7 radiotherapy departments, and 13 pathology departments. 


\section{References}

1 Mettlin CJ, Menck HR, Winchester DP, Murphy GP A comparison of breast, colorectal, lung, and prostate cancers reported to the National Cancer Data Base and the Surveillance, Epidemiology, and End Results Program. Cancer 1997;79:2052-2062.

2 Sainsbury R, Haward B, Rider L, Johnston C, Round $\mathrm{C}$ : Influence of clinician workload and patterns of treatment on survival from breast cancer. Lancet 1995;345:1265-1270.

3 Selby P, Gillis C, Haward R: Benefits from specialised cancer care. Lancet 1996;348:313-318.

4 Tarlov AR, Ware JE Jr, Greenfield S, Nelson EC, Perrin E, Zubkoff M: The medical outcomes study. An application of methods for monitoring the results of medical care. JAMA 1989;262:925-930.

5 Bailar JC III, Gornik HL: Cancer undefeated. N Engl J Med 1997;336:1569-1574.

6 Blumenthal D: Quality of health care part 1: Quality of care - what is it? N Engl J Med 1996;335:891-894.

7 Brook RH, McGlynn EA, Cleary PD: Quality of health care part 2: Measuring quality of care. N Engl J Med 1996;335:966-970.

8 Epstein AM: Sounding board the outcomes movement - Will it get us where we want to go? N Engl J Med 1990;323:266-270

9 King MT: The interpretation of scores from the EORTC quality of life questionnaire QLQ-C30. Qual Life Res 1996;5:555-567.
10 Payers P, Aaronson NK, Bjordal K, Sullivan M EORTC QLQ-C30 Scoring Manual, EORTC Data Center, Brussels, 1995

11 Rackl B, Mittermeyer C, Blümler H, Katenkamp D, Schmidtalbers U, Koller M, Engel J, Sauer H: Breast cancer - First results from four regions. Wien, UICC Management Meeting, Abstracts, 1997.

12 Hölzel D, Klamert A, Schmidt M: Krebs. Häufig keiten, Befunde und Behandlungsergebnisse. München, Zuckschwerdt Verlag, 1996.

13 Field MJ, Lohr KN: Clinical Practice Guidelines: Directions for a New Program. Washington, DC, National Academy Press, 1990.

14 Field MJ, Lohr KN: The omnibus budget reconciliation act of 1989; in [13] pp 107-127.

15 Gulliford MC: Evaluating prognostic factors: Implications for measurement of health care outcome. J Epidemiol Community Health 1992;46:323-326.

16 Hilner BE, McDonald MK, Penberthy L, Desch CE, Smith TJ, Maddux P, Glasheen WP, Retchin SM: Measuring standards of care for early breast cancer in an insured population. J Clin Oncol 1997; 15:1401-1408.

17 Naylor CD, Guyatt GH, for the Evidence-Based Medicine Working Group: Users' guides to the medical literature, $\mathrm{X}$ : How to use an article reporting variations in the outcomes of health services. JAMA 1996;275:554-558.
18 Sauer H (Hrsg): Empfehlungen zur Diagnostik, Therapie und Nachsorge des Mammakarzinoms; 6. Aufl. Tumorzentrum München, 1996; korrigierter und ergänzter Nachdruck 1997.

19 Engel J, Hölzel D, Sauer H, Arnholdt H, Busch M, Feddmann H-J: Mammakarzinom: Empfehlungen zu ärztlichen Berichten; Empfehlung zu Inhalten eines OP-Berichtes, eines Abschlußberichtes einer Chemotherapie, eines Strahlentherapieberichtes be Mammakarzinom. Geburtshilfe Frauenheilk 1997; 57:M26-M28

20 Engel J, Hölzel D, Sauer H: Mammakarzinom: Empfehlungen zu ärztlichen Berichten; Empfehlung zu Inhalten eines Arztbriefes bei Mammakarzinom. Geburtshilfe Frauenheilk 1997;57:M41-M45.

21 Engel J, Lebeau A, Arnholdt H, Hölzel D, Sauer H, Löhrs U: Mammakarzinom: Empfehlungen zu ärztlichen Berichten; Empfehlung zu Inhalten eines Pathologiebefundes beim Mammakarzinom. Geburtshilfe Frauenheilk 1997;57:M62-M66.

22 Donabedian A: The Definition of Quality and Approaches to Its Assessment. Ann Arbor, Health Administration Press, 1980.

23 Donabedian A: The quality of care. How can it be assessed? JAMA 1988;260:1743-1748.

24 Raabe NK, Kaaresen R, Fossaa SD: Hospital-related differences in breast cancer management Analysis of an unselected population-based series of 1,353 radically operated patients. Breast Cancer Res Treat 1997;43:225-235. 